\title{
AVIAN REPRODUCTIVE FUNCTION UNDER A COMBINED EFFECT OF PHYTOADAPTOGENS AND SOME FACTORS OF A SPACE FLIGHT
}

\author{
R. I. BOGATOVA, T. S. GURYEVA, Z. N. LEBEDEVA, G. WIKMAN ${ }^{1}$, S. PALM ${ }^{1}$, N. A. ROSLYAKOVA ${ }^{2}$
}

Institute of Biomedical Problems GMC RF, Moscow, Russia;

${ }^{1}$ Swedish Herbal Institute, Göteborg, Sweden; ${ }^{2}$ Joint Venture "Interstam AB", Moscow, Russia

\section{Received April 18, 1995}

Accepted June 6, 1996

\begin{abstract}
Bogatova R. I., Guryeva T. S., Lebedeva Z. N., Wikman G., Palm S., Roslyakova N. A.: Avian Reproductive Function under a Combined Effect of Phytoadaptogens and Some Factors of a Space Flight. Acta vet. Brno 1996, 65: 87-92.

Adult quail Coturnix coturnix japonica were used as test objects. A set of factors which had an impact on the avians included adaptogens supplemented to quail's dry diet and simulated space flight effects (shock and vibration) known for their physiological implications. Results of the experiment showed that administration of the composite phytoadaptogen following extreme physical impacts had a favorable effect on japanese quail ability to lay eggs. Ingredients of the composite adaptogen, the chosen dose and the pattern of adaptogen administration appear to block stress reactions to these physical impacts.
\end{abstract}

Physical stimulation, stress, egg production, phytoadaptogens, food

Rat experiments in biosatellites showed that mammals of this type are able to adapt to the conditions of a space flight. Nevertheless, such reversible functional changes as specific, related to weightlessness, and non-specific, related to stress development (F e d o r o v 1967; Fogt 1981; Philpott 1985; Plakhuta-Plakhutina 1979) were discovered in a number of organs and systems. The authors think that the share of such a non-specific component as stress in the reaction of the organism to the flight factors is very big and the fact that stress is responsible for a larger part of functional and structural changes occurring under these conditions cannot be discarded.

Undoubtedly, the results of animal experiments with simulated space conditions and a modified stress component will be interesting to analyze the mechanism of the effect of space flight factors.

A 9-day experiment "Incubator-2" with Japanese quail carried out in 1990 in conditions of weightlessness at the orbital station "Mir" showed the possibility of maintaining adult birds in weightlessness and also that these conditions had no effect on such fundamental processes as growth and development of birds. Nevertheless, all three female quail stopped laying eggs. Similar results were observed in a laboratory group of simultaneous control exposed to mechanical stimulation simulating factors of a space flight. Evidently start loads and dynamic weightlessness in the space and physical stimulation in land experiments were the reason why the quail were unable to lay eggs.

Autopsy of birds of these two groups revealed ovarian and oviducal hypotrophy and absence of mature follicles. These changes were reversible: female quail from "Mir" station started laying eggs 8 days after landing and laboratory birds resumed egg production 7 days after stress stimulation was interrupted. Their productivity remained on a pre-experiment level.

At present there are numerous pharmaceuticals (synthetic, herbal, of animal origin) regulating stress reactions in the organism and increasing its resistance to various harmful factors. Phytoadaptogens are widely known to have a broad spectrum of pharmacological effect (B r e khm a n 1957, 1968). Herbal drugs included into a group of phytoadaptogens have some advantages: absence of toxicity and a stage of a negative aftereffect, broad 
spectrum of action, they do not induce addiction even after a long use. Pharmacological effect of phytoadaptogens is usually manifested as an antistress effect ( $\mathrm{G} \mathrm{a} \mathrm{zen} \mathrm{ko} \mathrm{1978).}$

The use of phytoadaptogens in stock-breeding (Brekhman 1968; Fogt 1986; Gazenk o 1980; S erova 1979; Y a re me n k o 1990) and the data on their gonadotropic effect (Kirillov 1966; Ly a pustin a 1980) have been reported in literature.

Therefore, reversibility of ovulation cycle delay in female quail induced evidently by stress factors when they were at "Mir" station or exposed to physical stimulation in land experiments and the reported data on phytoadaptogen effect on reproductive functions in birds, have stimulated us to carry out these experiments.

The aim of these studies was to evaluate experimentally the effect of a complex phytoadaptogen on the reproductive functions of Japanese quail exposed to physical stimulation simulating some factors of a space flight.

\section{Materials and Methods}

Adult quail (Cotumix coturnix japonica) of the same generation and age ( 80 days) weighing $136.0 \pm 3.8 \mathrm{~g}$ on average were used in our experiments.

The criteria for selecting the quail for the experiment were high egg production and active behavior. A total of 40 quail ( 30 females and 10 males) were used in our trials. Every cage contained 2 males and 6 females to maintain "family" conditions.

A complex of factors the quail were exposed to, included phytoadaptogen treatment and simulated physiologically important factors of a space flight (shock overloads and vibration).

Shock instrument SU-1 and electrodynamic vibration stand (EDVS-400 A) whose platform was loaded with a cage of quail during 45-min stimulation, were used for simulating extreme physical stimulation. Shock acceleration and vibration of levels recorded as a rule at active stages (take-off and landing) of the space flight were used during experiments. The parameters of physical stimulation were similar to those recorded during landing.

A complex phytoadaptogen consisting of Eleutherococcus, Schizandra and Rhodiola rosea developed and produced at Swedish Herbal Institute was used in the experiment. The amount of the extract added to the food of test birds was calculated by body mass and it was $6 \mathrm{mg} / 110 \mathrm{~g}$. To exclude the losses of the product and secure complete consumption of phytoadaptogens, the extract was carefully mixed with small amount of food and, after it was totally consumed, the quail were given the remaining fodder.

The quail were divided into 5 groups: 4 test groups and 1 control (untreated with phytoadaptogen and unstimulated) maintained under usual laboratory conditions. Each group consisted of 6 laying hens and 2 males. Characteristics of the groups depending on the conditions of the experiment (the use of phytoadaptogen or physical stimulation) are shown in Table 1 .

During the first 7 days of the experiment the birds of group 2 (A) and group 4 (A+PS) were treated with phytoadaptogens.

On the 8th day quail of groups 3 (PS), 4 (A+PS) and 5 (PS+A) were exposed to stress of physical stimulation. Beginning from the 8th day of the experiment, the start of physical stimulation, birds of group 5 (PS+A) were treated with phytoadaptogens for 7 days more. Egg productivity of hens was recorded during the experiment.

At the end of the trial (15th day) the quail were decapitated and internal organs were macromorphologically analyzed.

Table 1

Experimental groups of quail

\begin{tabular}{|c|c|c|}
\hline $\begin{array}{l}\text { Group } \\
\text { number }\end{array}$ & Designations & Group description \\
\hline 1 & (C) & Control group kept in unchanged usual vivarium conditions. \\
\hline 2 & $\begin{array}{l}\text { (A) } \\
\text { Phytoadaptogen without } \\
\text { physical stimulation }\end{array}$ & $\begin{array}{l}\text { The group treated with phytoadaptogens } \\
\text { for the first } 7 \text { days. }\end{array}$ \\
\hline 3 & $\begin{array}{l}\text { (PS) } \\
\text { Physical stimulation }\end{array}$ & $\begin{array}{l}\text { The group exposed to physical } \\
\text { stimulation on the 8th day of experiment. }\end{array}$ \\
\hline 4 & $\begin{array}{l}\qquad(\mathrm{A}+\mathrm{PS}) \\
\text { Phytoadaptogen plus } \\
\text { physical stimulation }\end{array}$ & $\begin{array}{l}\text { Quail treated with phytoadaptogens for } 7 \text { days } \\
\text { and then on the } 8 \text { th day exposed to } \\
\text { physical stimulation. }\end{array}$ \\
\hline 5 & $\begin{array}{l}\text { (PS+A) } \\
\text { Physical stimulation } \\
\text { plus phytoadaptogen }\end{array}$ & $\begin{array}{l}\text { Quail exposed to physical stimulation on the 8th day } \\
\text { of the experiment and treated later } \\
\text { with phytoadaptogen for } 7 \text { days (from } 8 \text { th to } 14 \text { th day). }\end{array}$ \\
\hline
\end{tabular}

Note: (A), phytoadaptogens; (PS), physical stimulation. 


\section{Results and Discussion}

Analysis of the dynamics of changes in body mass showed practically no alterations in initial body mass of either test or control quail during 14 days of the experiment.

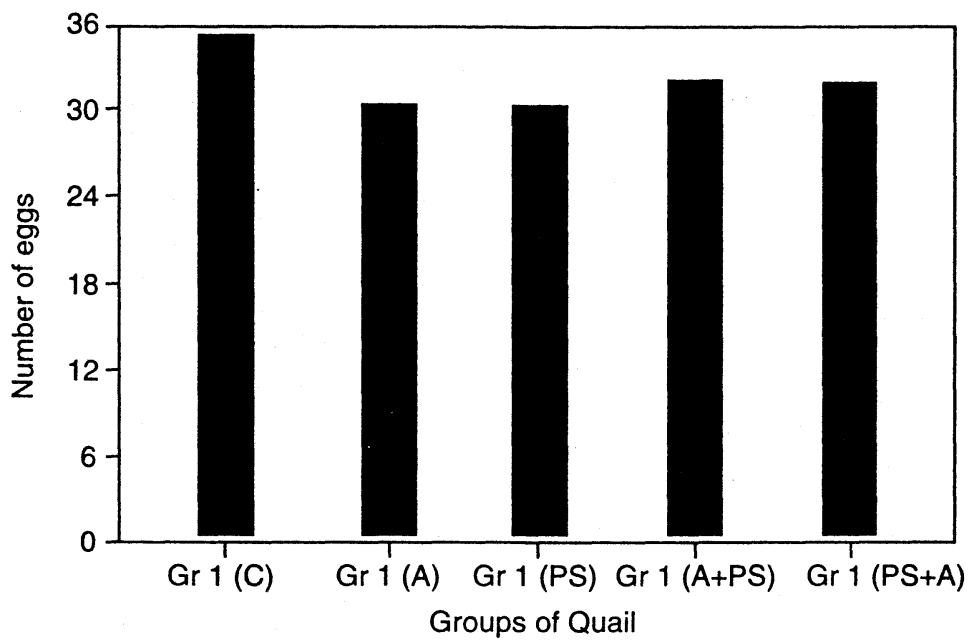

Fig. 1. Comparative characteristics of egg laying in hens of various groups before physical stimulation

During the first 7 days egg production in all test groups was practically the same (32-34 eggs/week) but it differed slightly from that of control group (36 eggs/week).

After groups $3(\mathrm{PS}), 4(\mathrm{~A}+\mathrm{PS})$, and $5(\mathrm{PS}+\mathrm{A})$ were exposed to physical stress stimulation

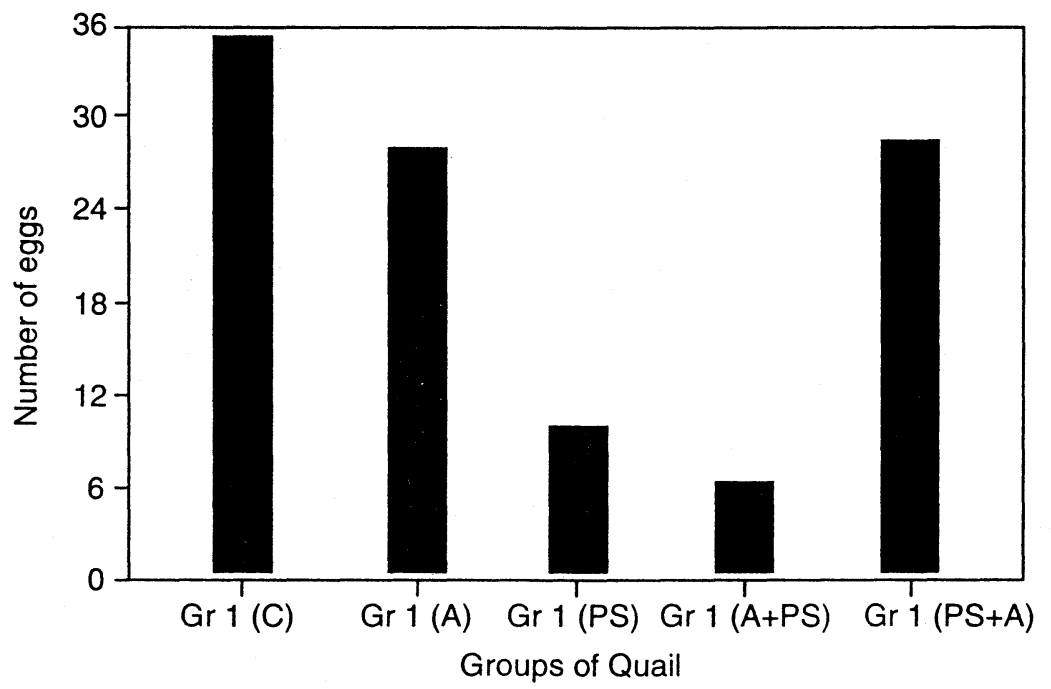

Fig. 2. Comparative characteristics of egg laying in hens of various groups after physical stimulation

(8th day of the trial) the following results were observed: quail of group 3 (PS) were still laying eggs for the following 2 days thanks to the eggs already formed in the oviduct but the 
number of produced eggs reduced twice on an average. During the next 4 days the hens did not produce any eggs.

The same negative dynamics in egg production and absence of egg production during the last 5 days of the experiment were observed in group 4 (A+PS), while in group 5 (PS+A) the hens went on laying eggs on all days of the experiment.

Comparative characteristics of egg production in different groups before and after physical stimulation are shown in Figures 1 and 2.

On the 15th day control and test quail were decapitated. Autopsy did not reveal any difference in internal organs mass between test and control quail. However, the mass of oviducts, their mass index and the index of of testes in birds of groups 3 (PS) and 4 (A+PS) exposed to stress stimulation were reduced considerably.

Macropreparate analysis showed thinning and narrowing of oviducts and other unfavorable symptoms in birds of groups 3 (PS) and $4(\mathrm{~A}+\mathrm{PS})$. This proves the observed effect of extreme physical stimulation on these quail.

Therefore, the results of the experiment show that phytoadaptogens added to a standard diet had no side effects on quail. This is confirmed by good food consumption, active behavior of quail during the trial and also by body mass dynamics.

The birds receiving standard diet with phytoadaptogens for a week did not differ from quail of other groups. Egg production was rather high and egg-laying cycle was normal.

Stress response was induced in birds of groups 3 (PS), 4 (A+PS) and 5 (PS+A) by extreme stimulation using various physical factors of a space flight. The majority of hens stopped laying eggs in response to this stimulation.

Thus, hens of group 3 (PS) have laid only 9 eggs during 7 days after stress stimulation which is only $25 \%$ of eggs produced by control birds during the same period.

The disorders in egg-laying cycle are confirmed by the results of autopsy and morphological analysis of internal organs. Thus, the index of ovaries and oviduct mass in hens of this group (PS) is much lower than in control birds.

Egg production in quail of group 4 (A+PS) treated with phytoadaptogens for 7 days before stress stimulation, has stopped after the exposure. Evidently, this can be explained either by too short period of the treatment or by insufficient preventive dose of the product. Probably we have to agree with the researchers [Metscherskay a 1972; Serova 1977] who think that phytoadaptogens effect manifests itself much better on "tired" functions.

Positive effect of phytoadaptogens on physiological status of quail exposed to stress was observed in group $5(\mathrm{PS}+\mathrm{A}$ ) where egg laying remained practically unaffected by stress stimulation.

Comparative characteristics of egg laying in control and test hens are shown in Figures 1 and 2 that demonstrate very clearly the reaction of quail to stress control. Evidently, addition of phytoadaptogens into the quail diet after stress stimulation reduces their excitability and negative response to stress.

Therefore, the experiment with addition of phytoadaptogens into a standard diet of quail to prevent and control stress induced by the effect of physical factors of a space flight, demonstrated its positive effect on birds treated with phytoadaptogens starting with the day of stress stimulation.

Antistress effect of phytoadaptogens, or to be more precise, regulation of stress response development in the organism, should be considered as their major pharmacological property underlying their biological effect - optimal protection of the organism from harmful factors.

Many specialists recognize the existence of a nonspecific stress component in the reaction of the organism of animals to some factors of a space flight. It can have some 
effect on their development in early postnatal period, on their reproductive functions, can induce pronounced changes in the maternal organism [Saratikov 1966; Zorikov 1986].

\section{Vplyv kombinovaného efektu fytoadaptogénov a niektorých faktorov vesmírneho letu na reprodukčné funkcie vtákov}

V experimente boli použité dospelé prepelice (Coturnix coturnix japonica). Medzi faktormi, úxinkujúcimi na vtáky, boli adaptogény, pridané do prepeličej suchej diéty, đalej vplyv vesmírneho letu (క̌ok a vibrácie), ktorých účinky na fyziologické funkcie organizmu sú známe.

Výsledky pokusu ukázali, že aplikácia fytoadaptogénu, ktorá nasledovala po pôsobení extrémnych fyzikálnych faktorov, mala priaznivý efekt na znásku vajec jap. prepelice. Zdá sa, že adaptogén v podanej dávke blokuje stresové reakcie na sledované fyzikálne faktory.

\section{Репродуктивная функция птиц при сочетанном воздействии растительных адаптогенов и некоторых факторов космического полета}

Результаты проведенных исследований показали, что растительный адаптоген сложной композиции, введеный в рацион питания взрослого японского перепела после применения $\mathrm{k}$ ним физических воздействий (ударные перегрузки и вибрация), оказывает влияние, в первую очередь, на снятие стрессовых реакций, вызванных примененными физическими воздействиями.

В группе птиц, получавших адаптоген и подвергавшихся физическим воздействиям после принятия препарата, не выявлено положительного действия на сохранения яицекладки японского перепела.

Таким образом, полученные данные дают основание предпогладать, что имеет значение не только прием адаптогена, но и схема его приема.

\section{References}

BREKHMAN I. 1957: Gin Seng. Leningrad, 180 p.

BREKHMAN I. 1968: Eleutherococcus. Leningrad, Nauka, 185 p.

FEDOROV N. 1967: The state of spermatogenesis in dogs Ugoliok and Veterok after a flight in satelite "Cosmos$110^{\prime \prime}$. Kosmich. Biologich. i Aviakosmich. Meditsina, 1, 3, 28-31.

FOGT H. 1981: Extract of Eleutherococcus roots in poultry diet. New Data on Eleutherococcus. Vladivostok, 61-62.

FOGT H. 1986: Liquid Eleutherococcus extract in the diet of laying hens infected with mycoplasma. New Data on Eleutherococcus. Vladivostok, 154-157.

GAZENKOO., GENIN A., ILIN E. et al. 1978: Major results of the experiment with mammals on biosatellite "Cosmos-782". Kosmich. Biologich. i Aviakosmich. Meditsina 12, 6: 43-49.

GAZENKO O., GENIN A., ILIN E. et al. 1980: Adaptation to weightlessness and its physiological mechanisms. Izvestia AN SSSR, Biology Series 1: 5-18.

KIRILLOV O. 1966. On the experience in pharmacological regulation of stress. Vladivostok.

LYAPUSTINA T. 1980: Eleutherococcus drugs in animal breeding. Moscow, Kolos, 64 p.

METSCHERSKAYA K. and RODIONOVA N. 1972: Effect of Acantopanax leaves on sex hormones activity. Remedies of the Far East. Vladivostok, 137-140.

PHILPOTT D., SAPP W., WILLIAMS C. et al. 1985: Reduction of spermatogonial population in rat testes flown on space Lab-3. Physiologist. Suppl. 28, 6: 211-212.

PLAKHUTA-PLAKHUTINA G. 1979: Weightlessness and artificial gravitation effects on the morphology of the thyroid gland. Arkhivy Anatomii, Gistologii i Embriologii 76, 3: 17-22.

SARATIKOV A. 1966: Some results of the search and studies of the CNS stimulants of herbal origin. Tomsk, $23 \mathrm{p}$.

SEROVA L. 1977: Changes in the level of gravitation as a stress factor. Kosmich. Biologich. i Aviakosmich. Meditsina 11, 5: 25-32. 
92

SEROVAL., IIINE., and NOSKIN A. 1979: Experimental conditions, selection and preparation of animals. Effect of dynamic factors of a space flight on animal organism. Moscow, Nauka: 7-13.

YAREMENKO K. 1990: Adaptogens as drugs in preventive medicine. Tomsk, 93 p.

ZORIKOV P. 1986: Eleutherococcus effect on egg production in hens. New Data on Eleutherococcus. Vladivostok, 158-160. 